\title{
Front Matter: Volume 9488
}

, "Front Matter: Volume 9488," Proc. SPIE 9488, Sensing for Agriculture and Food Quality and Safety VII, 948801 (17 June 2015); doi:

10.1117/12.2199550

SPIE Event: SPIE Sensing Technology + Applications, 2015, Baltimore, MD, United States 


\title{
PROCEEDINGS OF SPIE
}

\section{Sensing for Agriculture and Food Quality and Safety VII}

\author{
Moon S. Kim \\ Kuanglin Chao \\ Bryan A. Chin \\ Editors
}

21-22 April 2015

Baltimore, Maryland, United States

Sponsored and Published by

SPIE 
The papers included in this volume were part of the technical conference cited on the cover and title page. Papers were selected and subject to review by the editors and conference program committee. Some conference presentations may not be available for publication. The papers published in these proceedings reflect the work and thoughts of the authors and are published here in as submitted. The publisher is not responsible for the validity of the information or for any outc omes resulting from reliance thereon.

Please use the following format to cite material from this book:

Author(s), "Title of Paper," in Sensing for Agriculture and Food Quality and Safety VII, edited by Moon S. Kim, Kuanglin Cha o, Bryan A. Chin, Proceedings of SPIE Vol. 9488 (SPIE, Bellingham, WA, 2015) Article CID Number.

ISSN: 0277-786X

ISBN: '9781628416046

Published by

SPIE

P.O. Box 10, Bellingham, Washington 98227-0010 USA

Telephone +1 3606763290 (Pacific Time)· Fax +1 3606471445

SPIE.org

Copyright @2015, Soc iety of Photo-O ptic al Instrumentation Engineers.

Copying of material in this book for intemal or personal use, or for the intemal or personal use of specific clients, beyond the fa ir use provisions granted by the U.S. Copyright Law is authorized by SPIE subject to payment of copying fees. The Transactional Reporting Service base fee for this volume is $\$ 18.00$ per article (or portion thereof), which should be paid directly to the Copyright Clearance Center (CCC), 222 Rosewood Drive, Danvers, MA 01923. Payment may also be made electronically through CCC Online at copyright.com. Other copying for republication, resale, advertising or promotion, or any form of systematic or multiple reproduction of a ny material in this book is prohibited except with permission in writing from the publisher. The CCC fee code is 0277-786X/15/\$18.00.

Printed in the United States of America.

Public ation of record for individual papers is online in the SPIE Dig ital Library.

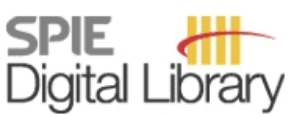

SPIEDigitalLibrary.org

Paper Numbering: Proceedings of SPIE follow an e-First publication model, with papers published first online and then in print. Papers are published as they are submitted and meet publication criteria. A unique citation id entifier (CID) number is assigned to each article at the time of the first publication. Utilization of CIDs allows articles to be fully citable as soon as they are published online, and connects the same identifier to all online, print, and electronic versions of the publication. SPIE uses a six-dig it CID article numbering system in which:

- The first four digits correspond to the SPIE volume number.

- The last two digits indic ate publication order within the volume using a Base 36 numbering system employing both numerals and letters. These two-number sets start with $00,01,02,03,04$, $05,06,07,08,09,0 A, 0 B \ldots$ 0Z, followed by 10-1Z, 20-2Z, etc.

The CID Number appears on each page of the manuscript. The complete citation is used on the first page, and an abbreviated version on subsequent pages. 


\title{
Contents
}

\author{
$\checkmark$ Authors \\ vii Conference Committee
}

\section{SESSION 1 SENSING FOR FOOD QUALITY AND SAFETY I}

948803 High throughput pathogen screening for food safety using magnetoelastic biosensors (Invited Paper) [9488-2]

948805 In-situ detection of multiple pathogenic bacteria on food surfaces [9488-4]

948806 Application of a LED-based reflectance sensor for the assessing in situ the lycopene content of tomatoes (Lycopersicon esculentum Mill.) [9488-5]

948807 Detection of salmonella on globe fruits using pulse excited magnetoelastic biosensors [9488-6]

\section{SESSION 2 SENSING FOR FOOD QUALITY AND SAFETY II}

948808 Bioenabled SERS substrates for food safety and drinking water monitoring (Best Paper Award) [9488-7]

$9488 \mathrm{OB}$ A biosensor based on magnetic resonance relaxation [9488-11]

9488 OC Nature-inspired magnetoelastic biosentinels for the detection of pathogenic bacteria in stagnant liquids (Best Paper Award) [9488-12]

\section{SESSION 3 RAMAN FOR FOOD QUALITY AND SAFETY}

9488 OE Raman-spectroscopy-based chemical contaminant detection in milk powder [9488-14]

9488 OF Screening of adulterants in powdered foods and ingredients using line-scan Raman chemical imaging [9488-15]

9488 OG Shifted excitation Raman difference spectroscopy: a potential tool for outdoor measurements in precision agriculture [9488-16]

\section{SESSION 4 HYPERSPECTRAL IMAGING FOR FOODS}

9488 ol Chemometric analysis for near-infrared spectral detection of beef in fish meal [9488-18] 
$94880 \mathrm{M}$ Classification of corn kernels contaminated with aflatoxins using fluorescence and reflectance hyperspectral images analysis [9488-22]

948800 Using NOAA/AVHRR based remote sensing data and PCR method for estimation of Aus rice yield in Bangladesh [9488-24]

$9488 \mathrm{OP}$ Pest damage assessment in fruits and vegetables using thermal imaging [9488-48]

\section{POSTER SESSION}

$9488 \mathrm{OQ}$ A rapid detection method of Escherichia coli by surface enhanced Raman scattering [9488-26]

9488 OR Research on identification and determination of mixed pesticides in apples using surface enhanced Raman spectroscopy [9488-27]

9488 OS Rapid detection of benzoyl peroxide in wheat flour by using Raman scattering spectroscopy [9488-28]

9488 OT Nondestructive detection of pork quality based on dual-band VIS/NIR spectroscopy [9488-29]

9488 OU Depth of penetration of a $785 \mathrm{~nm}$ wavelength laser in food powders [9488-30]

9488 oW The blocking reagent optimization for the magnetoelastic biosensor [9488-32]

948812 Production of an innovative fertilizer from organic waste: process monitoring by hyperspectral imaging [9488-38] 


\section{Authors}

Numbers in the index correspond to the last two digits of the six-digit citation identifier (CID) article numbering system used in Proceedings of SPIE. The first four digits reflect the volume number. Base 36 numbering is employed for the last two digits and indicates the order of articles within the volume. Numbers start with 00, 01, 02, 03, 04, 05, 06, 07, 08, 09, 0A, 0B...0Z, followed by 10-1Z, 20-2Z, etc.

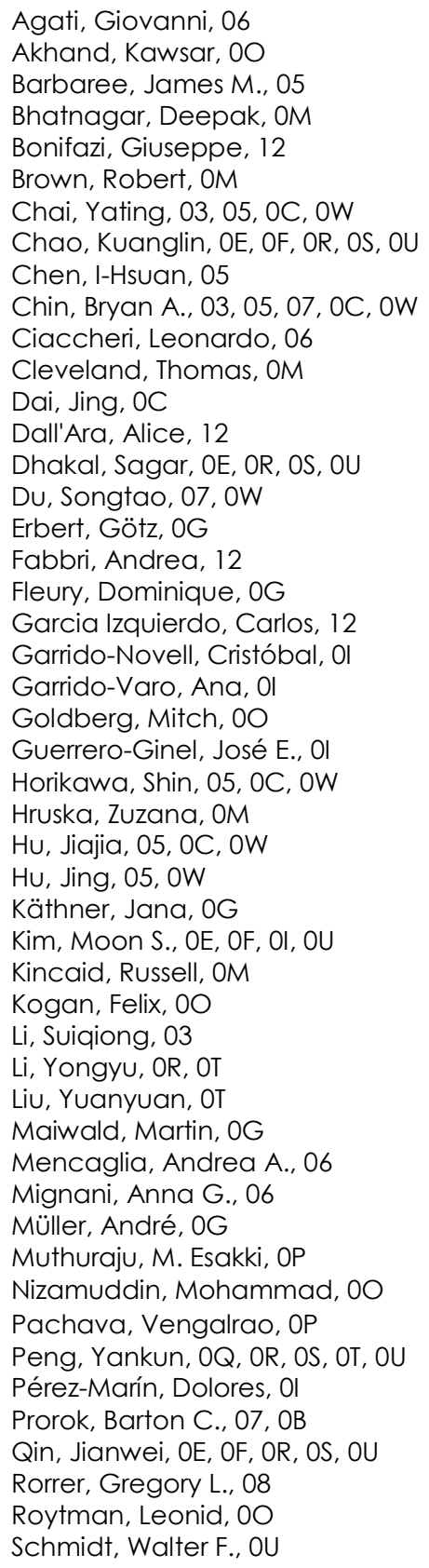

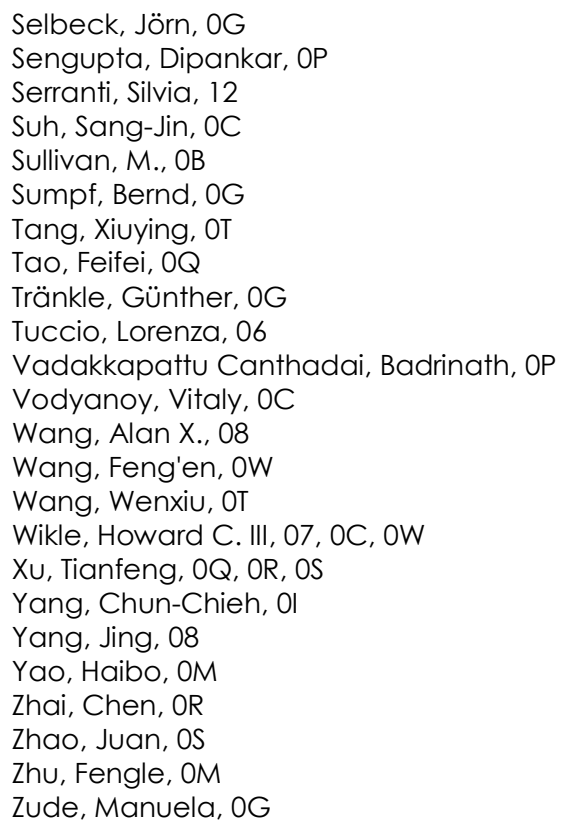


Proc. of SPIE Vol. $9488948801-6$

Downloaded From: https://www.spiedigitallibrary.org/conference-proceedings-of-spie on 25 Apr 2023 Terms of Use: https://www.spiedigitallibrary.org/terms-of-use 


\title{
Conference Committee
}

\author{
Symposium Chair
}

Wolfgang Schade, Clausthal University of Technology (Germany) and Fraunhofer Heinrich-Hertz Institute (Germany)

Symposium Co-Chair

Ming C. Wu, University of California, Berkeley (United States)

Conference Chairs

Moon S. Kim, USDA Agricultural Research Service (United States)

Kuanglin Chao, USDA Agricultural Research Service (United States)

Bryan A. Chin, Auburn University (United States)

Conference Program Committee

Arun K. Bhunia, Center for Food Safety Engineering, Purdue University (United States)

Suming Chen, National Taiwan University (Taiwan)

Byoung-Kwan Cho, Chungnam National University (Korea, Republic of)

Stephen R. Delwiche, USDA Agricultural Research Service (United States)

Ki-Bok Kim, Korea Research Institute of Standards and Science (Korea, Republic of)

Naoshi Kondo, Kyoto University Graduate School of Agriculture (Japan)

Kurt C. Lawrence, USDA Agricultural Research Service (United States)

Kangjin Lee, National Academy of Agricultural Science (Korea, Republic of)

Alan M. Lefcourt, USDA Agricultural Research Service (United States) Changying (Charlie) Li, The University of Georgia (United States) Renfu Lu, USDA Agricultural Research Service (United States) Bosoon Park, USDA Agricultural Research Service (United States) Yang Tao, University of Maryland, College Park (United States) Yankun Peng, China Agricultural University (China) Gang Yao, University of Missouri-Columbia (United States) Haibo Yao, Mississippi State University (United States) Yibin Ying, Zhejiang University (China)

Seung-Chul Yoon, USDA Agricultural Research Service (United States) 


\section{Session Chairs}

1 Sensing for Food Quality and Safety I

Howard Clyde Wikle III, Auburn University (United States)

Christoph Baver, KWS Group (Germany)

2 Sensing for Food Quality and Safety II

Suiqiong Li, Soochow University (China)

3 Raman for Food Quality and Safety

Kuanglin Chao, USDA Agricultural Research Service (United States)

4 Hyperspectral Imaging for Foods

Christoph Baver, KWS Group (Germany)

Seung-Chul Yoon, USDA Agricultural Research Service (United States)

5 Spectral Imaging for Foods

Seung-Chul Yoon, USDA Agricultural Research Service (United States) 